DOI: https://doi.org/10.32839/2304-5809/2021-4-92-29

UDC 616.12-053.82

Rodica Ignat

"Nicolae Testemițanu" State University of Medicine and Pharmacy

(Chisinau, Republic of Moldova)

\title{
CARDIOVASCULAR RISK FACTORS IN GROUP AGED 18-29 YEARS
}

Summary. Cardiovascular risk factors are the triggers of cardiovascular diseases. Early identification of cardiovascular risk factors in young people is of major importance, as most of these factors are reversible and therefore, their effects can be reduced by preventive interventions. The study includes the analysis of WHO official documents on chronic non-communicable diseases, behavioral and metabolic risk factors of these pathologies, as well as WHO STEPS reports on the results of cross-sectional studies for behavioral risk factors of non-communicable diseases. Prevalence of cardiovascular risk factors in young population aged 18-29 years varies in the analyzed surveys. Records show the presence of cardiovascular risk factors in the respective age group. Identification of cardiovascular risk factors in young people and early preventive interventions can reduce cardiovascular diseases in old age.

Keywords: cardiovascular risk factors, anthropometric parameters, serum lipids, cholesterol, STEPS survey.

Родіка I.

Державний університет медицини та фрармакології імені Миколи Тестеміцяну

(Кишинів, Республіка Молдова)

\section{ФАКТОРИ СЕРЦЕВО-СУДИННОГО РИЗИКУ В ГРУПІ У ВІКУ 18-29 РОКІВ}

\begin{abstract}
Анотація. Фактори ризику серцево-судинних захворювань є причиною серцево-судинних захворювань. Виявлення фракторів ризику серцево-судинних захворювань у молодих людей на ранньому етапі має велике значення, оскільки більшість 3 цих фракторів зворотні, і тому їх вплив можна пом'якшити за допомогою профрілактичних втручань. Дослідження включае аналіз офріційних документів ВООЗ про хронічні неінфекційні захворювання, поведінкові і метаболічні фрактори ризику даної патології, а також звіти BOO3 STEPS про результати перехресних досліджень поведінкових фракторів ризику неінфекційних захворювань. Поширеність фракторів ризику серцево-судинних захворювань серед молодого населення 18-29 років варіюеться в аналітичних дослідженнях. Фактичні дані свідчать про наявність фракторів ризику серцево-судинних захворювань в цій віковій групі. Виявлення факторів ризику серцево-судинних захворювань у молодих людей і ранні профрілактичні втручання можуть знизити ризик серцево-судинних захворювань в літньому віці.
\end{abstract}

Ключові слова: фрактори ризику серцево-судинних захворювань, антропометричні параметри, ліпіди сироватки крові, холестерин, дослідження STEPS.

Tntroduction. Noncommunicable diseases (NCDs), such as cardiovascular and metabolic diseases are the leading cause of death globally $[1 ; 2]$. The increase in noncommunicable diseases is determined by behavioral risk factors: smoking, insufficient physical activity, unhealthy diet and excessive alcohol use, which have a major impact on cardiovascular morbidity and mortality. Metabolic changes and high blood pressure, excess body weight/obesity, hyperglycemia and hyperlipidemia increase the risk of heart diseases [3-6]. Early identification of cardiovascular risk factors in young people and delimitation of the risk group in this age group it is of critical importance, as most of these factors are reversible and therefore their effects can be reduced by individualized preventive interventions [7].

As about the global burden preoccupation of noncommunicable diseases, the World Health Organization (WHO) has developed the STEPS Methodology (Chronic Disease Risk Factor Surveillance Instrument) to strengthen the surveillance of major chronic noncommunicable diseases and risk factors in the adult population. The STEPS methodology focuses on non-communicable diseases, including ischemic heart diseases, cerebrovascular diseases, hypertensive heart diseases, metabolic diseases, on assessment and monitoring of major cardiovascular risk factors. The STEPS instru- ment covers three levels of data: information on risk factors through survey (STEP 1); physical measurements (STEP 2) and collection of blood samples for biochemical analysis (STEP 3) [8] .

Aim of study. Analysis of bibliographic sources of WHO STEPS surveys on the evaluation of cardiovascular risk factors in young population aged 18-29 years.

Materials and methods. WHO official documents on chronic non-communicable diseases, behavioral and metabolic risk factors for chronic non-communicable diseases and 144 reports on the results of cross-sectional STEPS surveys for non-communicable disease risk factors from different countries were analyzed, out of which 14 STEPS surveys were selected, that met the criteria for estimating cardiovascular risk factors in young age group 18-29 years. The results of the studies in this context from PubMed online database were also analyzed.

Results and discussions.

Tobacco consumption. Smoking tobacco products, including passive smoking, is a major cardiovascular risk factor for the development of cardiovascular diseases [3]. The results of some analyzed STEPS surveys show that the rate of current smokers at the time of participation in the study among young people aged 18-29 years was high representing $27,4 \% \quad(44,5 \%$ men and 
$7,4 \%$ women) in young people from the Republic of Moldova [9], 31,3\% (47,7\% men and 14,0\% women) in those from Belarus[10] and 33,8\% (59,5\% men and $7 \%$ women) in those from Georgia [11]. Another STEPS survey conducted in Uzbekistan estimates a lower rate of active smokers in young population aged 18-29 years representing $12,1 \%$ (22,0\% men and 1,3\% women) [12]. Several results of STEPS surveys analyzed from different countries scored a rate from 6,2 to $19,8 \%$ of current smokers at the time of participation in the study among young people aged 18-29 years [13-22]. All the results of the analyzed STEPS surveys recorded statistically significant differences between the rate of current male smokers [9-22].

The rate of daily smokers among tobacco products consumers in the age group 18-29 years analyzed within the results of STEPS surveys in Moldova was $89,8 \%$, the rate of men being higher $-90,1 \%$ than that recorded in women $-87,3 \%$ [9]. Similar data were presented in Belarus STEPS survey, which estimates a rate of $87,6 \%$ of daily smokers among smokers $(92,0 \%$ men and $71,7 \%$ women) [10]. A lower level of daily smokers among the young population aged 18-29 years compared to the analyzed studies were obtained in Uzbekistan STEPS survey being 49,2\% in the respective age group, but recording a higher rate among women 50,9\% compared to men 49,1\% [12].

In the STEPS surveys it was also estimated the age at which people from reference group started smoking. Thus, the young people from island countries (Anguilla and St. Vincent) started to smoke at the age of 14,8 years (men from 14,7 years and women from 15,6 years) [15; 19]. Those from Belarus at the age of $-16,1$ years (men at 16,3 years, women at 17,3 years) [10], compared to the young people from Uzbekistan who started to smoke at a later ager - 19,3 years (women from this age group started to smoke earlier - 17,3 years, and men at 19,4 years) [12]. The STEPS survey conducted in Georgia reports that the men from the age group 18-29 years started to smoke earlier at 17,4 years compared to women at $-18,3$ years [11]. At the same time, Moldova STEPS survey shows that in young age group 18-29 years there were almost no statistically significant differences between men and women in the mean age at onset of smoking, this being 17 years [9].

The data from the analyzed studies prove that the majority of young smokers from this age group 18-29 years, consumed manufactured cigarettes [9-22] and 10,7\% among male smokers from Belarus in this age group used electronic cigarettes [10].

In STEPS surveys it was also estimated the quantity of cigarettes used daily by smokers. Thus, it was determined that in Uzbekistan young people from age group 18-29 years smoked in average a smaller number of manufactured cigarettes (men - 6.9 and women - 6,3 cigarettes per day) [12]. In Belarus, young people from the same age group smoked in average 13,6 manufactured cigarettes per day (men - 14,3, women - 9,8) [10]. Approximately similar data reported Moldova STEPS survey where young people smoked daily in average 15,3 manufactured cigarettes per day (men - 16,1, women -9,2) [9].
An important measure in the prevention of non-communicable diseases in the section of smoking is the abandonment of using tobacco products, which is also evaluated in STEPS surveys. The highest rate of the number of young smokers aged 18-29 years, who tried to quit smoking during the last year of $69,8 \%$ was recorded in the study from Uzbekistan (men - 70,0\% and women $-65,8 \%$, with statistically significant differences) [12]. Lower results were reported in the studies from Moldova and Belarus. Thus, about $36,9 \%$ out of the number of young smokers from Moldova tried to quit smoking during the last year (37,5\% men and $32,7 \%$ women), [9] and the rate of actual smokers in Belarus that tried to quit smoking during the last year was $35,6 \%(36,4 \%$ men and 32,6\% women) [10]. Another study estimated a lower rate among the young smokers aged 18-29 years from Georgia, who during the last year tried to quit smoking (19,0\%) (19,9\% among men and 19,0 among women [11].

Another event analyzed in the STEPS surveys is passive smoking. Long-term exposure to passive smoking is associated with increased risk of coronary heart diseases by 25\%-30\% [23]. About $18,4 \%$ of young people aged 18-29 years have been exposed to tobacco smoke at home, men have been exposed to tobacco smoke in $19,8 \%$ compared to women $16,9 \%$ reports the study from Moldova [9]. Almost similar data on exposure to tobacco smoke at home of the young people aged 18-29 years have been recorded in Belarus STEPS survey being of $18,5 \%$ (men $-19,3 \%$, women - 17,7\%) [10]. Uzbekistan STEPS survey showed that, the rate of young people aged 18-29 years exposed to tobacco smoke at home was $22,0 \%$ without statistically significant differences between sexes [12]. At the same time, $51,5 \%$ of young people from Georgia are exposed to tobacco smoke, men recording statistically significant differences $58,0 \%$ compared to women $44,7 \%$ [11].

The rate of young people aged 18-29 years exposed to tobacco smoke at workplace in the analyzed studies was different being of 30,2\% (38,8\% men and 20,3\% women) in Republic of Moldova, $19,1 \%(28,2 \%$ men and $10,6 \%$ women $)$ in Georgia, $16,5 \%(24,4 \%$ men and $8,5 \%$ women) in Belarus, and $14,9 \%(22,3 \%$ men and $6,5 \%$ women $)$ in Uzbekistan. In all the analyzed surveys, men recorded statistically significant differences compared to women [9-12].

Alcohol consumption. Excessive alcohol consumption is associated with an increased risk of hypertension, fibrillation, cerebrovascular accident and increased mortality due to these pathologies [24]. The results of the analyzed STEPS surveys estimate that $61,7 \%$ of young people aged 18-29 years from the Republic of Moldova (68,6\% men, 53,7\% women) and 63,8\% of young people of the same age from Anguilla (72,0\% men, 55,9\% women) have been current alcohol consumers at the moment of participation to survey $[9 ; 15]$. In the same context Belarus STEPS survey remarks a rate of $48,6 \%$ of alcohol current consumers among the young people of the same age $(58,3 \%$ men, 38,3\% men) [10]. Almost similar data were recorded in Georgia STEPS survey, estimating $45,9 \%$ of young people from 
this age category being alcohol current consumers $(61,3 \%$ men, $29,8 \%$ women) [11]. A lower rate of alcohol current consumers in young age group 18-29 years was recorded in Uzbekistan STEPS survey - $11,2 \%(18,3 \%$ among men and $3,3 \%$ among women) [12]. The data of the analyzed surveys show statistically significant differences among young men compared to women [9-12].

A major cardiovascular risk factor is considered alcohol consumption in volume of 6 or more standard doses for each occasion for men and 4 or more doses for women [24]. Some STEPS surveys documented in young age group 18-29 years different data related to harmful alcohol consumption. Thus, this rate being of 9,1\% $(33,2 \%$ men and 4,5\% women) in Georgia [11], 15,2\% (25,0\% men and 4,9\% women) in Belarus [10] and 24,1\% (30,8\% men and $17,5 \%$ women) in Anguilla [15]. In the same context Uzbekistan STEPS survey recorded in age group 18-29 years a lower rate $(3,2 \%)$ of alcohol consumption in harmful doses for health, but still $6 \%$ were recorded among men while women from this age group did not recorded alcohol consumption in harmful doses for health [12]. In all analyzed surveys men also recorded statistically significant differences on harmful alcohol consumption compared to women [10-12]. The importance of detected results in Moldova STEPS survey is relevant, that did not record in age group 18-29 years cases of alcohol consumption of 6 or more standard doses for any occasion for men and 4 or more doses for women [9].

Another problem approached in this chapter within STEPS surveys was estimated the average number of alcohol consumption occasions for the last 30 days among the current young consumers of alcohol. Thus, Uzbekistan WHO STEPS survey denotes that the young people aged 18-29 years lcohol consumers used alcohol for the last 30 days in 3,6 occasions ( 3,8 occasions men, 2,5 occasions women) [12]. The young people from the same age group from the Republic of Moldova, used alcohol in 2,7 occasions for the last 30 days at the moment of participation to survey ( 3,1 occasions men, 2,1 occasions women) [9]. Similar data were recorded among the young people aged 18-29 years from Belarus STEPS survey, who used alcohol in 2,8 occasions for the last 30 days (3,2 men and 2,2 women) [10]. On the other hand, Belarus STEPS survey specifies that the current young consumers of alcohol used for the last 30 days in average 4,5 standard doses on an occasion of drinking (5,4 standard doses were used among men and 3,1 standard doses were used among women)[10]. Another Uzbekistan survey estimated that the young people aged 18-29 years consume 3,8 standard doses on a single occasion (4,1 in men and 2,3 in women) [12]. It is plausible that among the young people aged 18-29 years from the Republic of Moldova the consumption of standard doses used on a single occasion is lower, representing 3,1 (3,8 men and 2.2 women) [9]. Thus, obtaining the most comprehensive and perfect information on alcohol consumption is a necessity in clinical aspect.

Consumption of fruits and vegetables. In addition to unhealthy habits, such as alcohol and tobacco consumption, low consumption of fruits and vegetables is also a risk factor for the deve- lopment of non-communicable diseases [3]. WHO recommends daily consumption of at least 5 portions (400 gr.) of fruits and vegetables per day as a measure to prevent the development of non-communicable diseases [3]. Thus, the results of STEPS surveys conducted in Republic of Moldova [9] and Georgia [11] prove that the consumption of fruits in age group 18-29 years complies with WHO recommendations [3]. At the same time, $68,1 \%$ of the young population aged 18-29 years from Republic of Moldova consumes less than 5 portions of vegetables per day $(68,3 \%$ men and $67,8 \%$ women $)$ [9]. At the same time, $35,8 \%$ of young people aged 18-29 years from Georgia consume 5 or more portions of vegetables per day, but on the other hand $64,2 \%$ of young people from the same age group consume less than 5 portions of fruits per day [11]. Some surveys conducted in different geographic areas show a consumption of fruits and vegetables among young people under the level recommended by WHO, being less than 2 portions of fruits per day and less than 5 days per week, without statistically significant differences between sexes $[13 ; 14 ; 16 ; 17 ; 19]$. Africa (Zambia) STEPS survey denotes that the young people aged 18-29 years consumed less than a portion of vegetables per day, and 6,2 days per week [22]. These discrepancies in the quantity and frequency of use of fruits and vegetables in different surveys are probably related to geographical or cultural differences in populations.

Consumption of meals outside of home. The STEPS surveys also analyzed the average number of meals consumed outside of home, that is associated with poor diet both in fruits and vegetables as well as in excessive consumption of saturated fats, salt and sugars [25]. In young age group 18-29 years from the Republic of Moldova the consumption of meals outside of home was recorded by 2,1 times per week $(2,5$ times in men and 1,6 times in women) [9]. Similar data were recorded in young people from the same age group from Uzbekistan, who consumed meals outside of home by 2,6 times per week, men by 3 times per week and women by 2,1 times per week [12]. Young people aged 18-29 years from Belarus consumed meals outside of home by 1,5 times per week and men also served the meal outside of home more often (1,7 times per week) than women (1,3 times per week) [10]. Thus, the frequent eating outside of home requires health diet education of individuals from reference group.

Consumption of food salt. Excessive food salt is associated with an increased risk of high blood pressure and cardiovascular diseases [3]. WHO estimates about 1,65 million deaths worldwide caused by cardiovascular diseases are associated to excessive intake of salt [3]. Reducing salt intake can directly improve health outcomes and can indirectly reduce overall mortality through its beneficial effects on blood pressure. WHO recommends that adults consume salt less than $5 \mathrm{~g}$ daily [3].The results of analyzed STEPS surveys on consumption of salt among the young population aged 18-29 years are different. In Republic of Moldova $25,2 \%$ of the young people of this age consume salt in excessive quantities $(26,9 \%$ men and $23,3 \%$ women) [9]. Uzbekistan STEPS survey proves 
that over one third of young people from the same age group (35,7\%) added permanently salt, condiments or salted sauces while cooking meals at home, without statistically significant differences between the sexes [12]. The same survey estimated that $15,2 \%$ of young people aged $18-29$ years added salt in foods permanently or frequently cooking them (women 17,4\% and men 13,2\%) [12].

Physical activity. Insufficient physical activity causes approximately 3.2 million deaths annually. The risk of death in people with insufficient physical activity increases by $20-30 \%$. [26] While regular physical activity reduces the risk of cardiovascular diseases, including high blood pressure, diabetes and other noncommunicable diseases [27]. According to WHO global recommendations on physical activity for health, adults should do at least 150 minutes of moderate-intensity aerobic physical activity throughout the week or do at least 75 minutes of vigorous-intensity aerobic physical activity or an equivalent combination of moderate and vigorous-intensity activity, reaching at least 600 MET minutes [23]. In this order of ideas, the results of Moldova STEPS survey denote that in $9,2 \%$ of young people aged 18-29 years the level of physical activity does not comply with WHO recommendations on physical activity for health $(8,3 \%$ in men and $10,3 \%$ in women) [9]. Similar results were proved in Belarus STEPS survey too, that shows that $9,7 \%$ of young people from the respective age group exercise a reduced level of total physical activity (men $-7,7 \%$, women $-11,8 \%$ ) [10]. Other surveys estimate that $14,5 \%$ of young people aged 18-29 years from Georgia and 15,6\% of young people of the same age from Uzbekistan do not meet WHO recommendations of physical activity. Both surveys proved statistically significant differences among women 20,0\% (Georgia) and $23,3 \%$ (Uzbekistan) compared to men $8,6 \%$ $[11 ; 12]$. The results of STEPS surveys from many countries except for those European denote a rate up to $55 \%$ of young people aged $18-29$ years to which the physical activity does not comply with WHO recommendations [13-15; 17-21]. From the other hand the analyzed STEPS surveys from European region prove more than $60 \%$ of young people from age group 18-29 years have a high level of physical activity according to WHO global recommendations on physical activity, with a statistically significant difference in men than in women [9-12].

Blood pressure. Blood pressure is a major risk factor for coronary heart diseases and cerebrovascular accidents, being in $13 \%$ the cause of death worldwide [23]. The mean value of blood pressure recorded in majority of the analyzed surveys in young people aged between 18-29 years was within normal limits [9-12]. According to Moldova STEPS survey about $11 \%$ of young people aged 18-29 years reported that they had never had their blood pressure measured by a doctor or other health worker. However, in $5,2 \%$ of young people from the respective age group was diagnosed with blood pressure before the last 12 months of participation to survey $(4,6 \%$ men and 5,8\% women) and in 2,5\% of young people of the same age the blood pressure was diagnosed more than 12 months prior to participation to survey $(1,1 \%$ men and $4,0 \%$ women)[9]. Belarus STEPS survey denotes that among the young people aged $18-29$ years $-17,9 \%(18,7 \%$ men and $16,0 \%$ women) knew that they have increased values of the blood pressure or had diagnosed blood pressure and underwent antihypertensive treatment prescribed by a doctor or health worker[10]. To be noted in this context that the analyzed STEPS surveys point out a rate of blood pressure $(\geq 140 / 90 \mathrm{mmHg}$ ) among the young persons aged $18-28$ years of $10,6 \%(15,4 \%$ men and $0,5 \%$ women) in young people from Georgia [11], 10,7\% (15\% men and 5,9 women) in those from Uzbekistan [12], $11,0 \%$ (13,9 men and 8,0\% women) in young people from Belarus [10]. A high rate of blood pressure values $(\geq 140 / 90 \mathrm{mmHg})$ was estimated in young people from the Republic of Moldova, being of $16,0 \%(20,4 \%$ men and $10,9 \%$ women) [9]. The blood pressure prevalence $(\geq 160 / 100 \mathrm{mmHg})$ in young people from this age group was detected in $1,6 \%$ (2,6\% men and $0,2 \%$ women) of young people from Georgia [11], in 2,1\% (3,5\% men and $0,5 \%$ women) from Uzbekistan [12], in $2,3 \%(3,0 \%$ men and 1,6\% women) from Belarus [10] and in $4,0 \%$ of young people from the Republic of Moldova $(5,8 \%$ men and $1,8 \%$ women) [9]. The evaluated researches show data with reference to people undergoing antihypertensive treatment. The rate of these young people in Georgia survey was $11,8 \%$ (16,7\% men and 7,0\% women) $[11] ; 13,7 \%(17,0 \%$ men and 10,3\% women) from Belarus [10]. Higher rates were recorded among young people from Uzbekistan $15,1 \%$ (18,1 men and 11,9 women) [12] and from the Republic of Moldova 16,9\% (20,6\% men and $12,7 \%$ women) [9]. The prevalence of systolic blood pressure (TAs) $\geq 160$ and/or diastolic blood pressure (TAd) $\geq 100 \mathrm{mmHg}$ among young peoples aged comprised 18-29 years who were undergoing antihypertensive treatment, participants within the STEPS surveys were of $6,9 \%$ (7,0 men and 6,9 women) in young people from Uzbekistan [12], 5,3\% (6,4\% men and 4,3 women) from Belarus [10], 5,0\% (6,0\% in men and $3,8 \%$ in women) from Republic of Moldova [9], 3,0\% in those from Georgia (4,1\% men and 0,5\% women) [11].

Overweight and obesity. Multiple research worldwide showed that there is a strong association between body mass index (BMI) and cardiovascular risk [28-32]. The results of the analyzed STEPS surveys show that $25,8 \%$ of young people from the Republic of Moldova, from age group 1829 years were overweight BMI $\geq 25(34,1 \%$ in men and $15,5 \%$ in women) and, $7,3 \%$ recorded $\mathrm{BMI}$ $\geq 30,0$ being obese (5,5\% men and $9,5 \%$ women) [9]. Georgia survey shows a rate of $22,8 \%$ of overweight young people $(27,6 \%$ men and 17,6 women) and $13,9 \%$ obese (18,3\% men and 9,2\% women) [11]. Higher rates have been recorded among young people of the same age in the study from $\mathrm{Ku}-$ wait $37.4 \%$ - overweight $(41,2 \%$ men, $32,2 \%$ women) and 28,2\% - obese (28,5\% men, $27,9 \%$ women) [17]. Study from Anguilla shows that 30,9\% young people are obese (29,7\% mee, 32,2 women) and $25,5 \%$ overweight (25,4\% men, 26,6 women) [15]. Another anthropometric parameter analyzed in STEPS surveys was waist circumference, WHO reference limits were used to determine abdominal 
obesity [8; 29; 30]. Belarus STEPS survey recorded in young people aged 18-29 years the average of waist circumference more than $95 \mathrm{~cm}$ in men in $19,1 \%$ cases and more than $80 \mathrm{~cm}$ in women in $27,0 \%$ [10]. The same survey proves that the average of hips circumference in age group 18-29 years was $94,2 \mathrm{~cm}$ for men and $94,5 \mathrm{~cm}$ in women. The average of waist-to-hips ratio in young people from the same age group was 0,9 in men and 0,8 in women [10].

No complex approach to the values of BMI, waist circumference, hip circumference in STEPS surveys has not been highlighted.

Metabolic risk factors. Diabetes is a major and trigger risk factor for cardiovascular diseases [33]. Increased basal glycemia is a risk factor for the further development of diabetes and cardiovascular diseases [34]. The analyzed WHO STEPS surveys show that in young population aged 18-29 years from the Republic of Moldova 4,8\% recorded increased basal glycemia $\geq 5,6 \mathrm{mmol} / \mathrm{l}$, being $5,0 \%$ among women and $4,7 \%$ in men [9]. The same survey proves that in $5,3 \%$ of young people from age group 18-29 years, was detected the value of glucose $\geq 6,1 \mathrm{mmol} / \mathrm{l}$ in capillary blood and at the moment of participation to survey the young people had medication for diabetes, men presenting a higher rate $6,1 \%$ than women 4,5\% [9]. Another Uzbekistan survey estimated that $7,9 \%$ of young people had increased basal glycemia, proving the same statistically significant differences in women $8,7 \%$ in respect of $7,2 \%$ in men and $5,0 \%$ of young people from the analyzed age group had medication for diabetes $(5,7 \%$ in men and $4,1 \%$ in women) [12]. Georgia STEPS survey presented a smaller rate of increased basal glycemia in young population aged 18-29 years being of $0,1 \%$ [11].

Dyslipidemia (high LDL cholesterol, hypertriglyceridemia, low HDL cholesterol) is a major risk factor for cardiovascular diseases [34]. In this context the STEPS surveys analyzed the total cholesterol and HDL cholesterol. In young population aged 18-29 years from Republic of Moldova the average value of total cholesterol with increases level $\geq 5,0 \mathrm{mmol} / \mathrm{l}$ represented $17,8 \%$, with statistically significant difference in women from this age group $20,0 \%$ in respect of $15,5 \%$ in men [9]. A higher rate of total cholesterol values $39,0 \%$ was recorded among young people from the same age group from Uzbekistan and the same young women from this age group recorded statistically significant differences higher $45,7 \%$ compared with men $32,9 \%$ [12]. The same survey proves that $6,0 \%$ of young persons aged 18-29 years had increased total cholesterol $\geq 6,2 \mathrm{mmol} / \mathrm{l}$ in capillary blood registering statistically significant differences higher $7,9 \%$ among women from this age group than in men 4,2\% [12]. Belarus STEPS survey estimated that among the young people aged $18-19$ years the level of total cholesterol $\geq 6,2 \mathrm{mmol} / \mathrm{l}$ was $3,4 \%$ (3,2\% in men and $3,7 \%$ in women) [10]. A much smaller rate of level of average values of total cholesterol in age group 18-29 years was recorded in Georgia STEPS survey being of $0,2 \%$ [11]. Moldova STEPS survey showed that the average level of HDL cholesterol concentration was $1,3 \mathrm{mmol} / \mathrm{l}$ among young people aged $18-29$ years, $1,3 \mathrm{mmol} / \mathrm{l}$ in men and $1,4 \mathrm{mmol} / \mathrm{l}$ in women [9]. This survey also proves that the rate of young people with cardiovascular risk for HDL $(<1,03 \mathrm{mmol} / \mathrm{l}$ for men and $<1,29 \mathrm{mmol} / \mathrm{l}$ for women) from the same age group was $31,7 \%$ among men and $41,2 \%$ in women [9]. Other surveys recorded rates higher for HDL levels with cardiovascular risk among the young people aged $18-29$ years, $47,3 \%$ in men and $56,7 \%$ in St. Vincent [19], 49,4\% in men and $50,4 \%$ in women in Oman [18], $57,5 \%$ in men and $60,1 \%$ in women in Kenia [16]. The highest rate in this context was reported in Uganda STEPS survey being $70,1 \%$ among men and $67.5 \%$ among women [20]. Belarus STEPS survey showed a lower rate of decreased HDL levels in young population aged 18 -29 years being of $29,1 \%$ in men and $30,5 \%$ in women [10].

Data related to elevated LDL cholesterol level $(\geq 3.4 \mathrm{mmol} / \mathrm{L})$ in age group $18-29$ years were reported only in Kuwait STEPS survey being 28,7\% (35,3\% men and $22,3 \%$ women) [17]. Thus, the identification of this risk factor among the young people from the respective age group also represents a necessity in clinical aspect.

Triglycerides were estimated only in some STEPS surveys. Similar data for triglycerides level ( $\geq 1,7 \mathrm{mmol} / \mathrm{L})$ in young population aged 18 29 years were related in Kuwait and Oman survey being $17,6 \%(26,0 \%$ men, $9,1 \%$ women $)$ and $(17,4 \%$ men, $17,8 \%$ women). This research reported that $11,8 \%$ of young people from the same age group from Kuwait the level of triglycerides was $\geq$ $2.0 \mathrm{mmol} / \mathrm{L}(17,2 \% \mathrm{men}, 6,4 \%$ women $)$ and those from Oman was $12.5 \%$ ( $12,7 \%$ men, $12,2 \%$ women) $[17 ; 18]$. St. Vincent STEPS survey showed a lower rate of triglycerides levels $\geq 1,7 \mathrm{mmol} / \mathrm{L}$ being of 5,3\% among men and $8,2 \%$ among women. The survey also reported that $2,7 \%$ men and $6,4 \%$ women from age group 18-29 years had the level of triglycerides $\geq 2.0 \mathrm{mmol} / \mathrm{L}$ [19].

However, it should be noted that there is a certain heterogeneity between the analyzed studies, explained by different limits used to define the components of dyslipidemia.

In all analyzed STEPS surveys the summary risk factors combined for cardiovascular diseases with $0,1-2$ or 3-5 risk factors: current daily smoking, consumption of less than five portions of fruits and/or vegetables per day, non-compliance with WHO recommendations on physical activity for health $(<150$ minutes of moderate physical activity per week or its equivalent), overweight or obesity (IMC $\geq 25 \mathrm{~kg} / \mathrm{m}^{2}$ ), high blood pressure (TAs $\geq 140 \mathrm{mmHg}$ and/or TAd $\geq 90 \mathrm{mmHg}$ ) had not been estimated in age group 18-29 years [9-22].

Conclusions. According to the results of the STEPS surveys analyzed in young population aged 18-29, there are convincing data on the presence of cardiovascular risk factors. Thus, the behavioral risk factors have been extensively analyzed in the respective age group and report a high rate among young people aged 18-29. Metabolic risk factors were less estimated in this age group. Identification of cardiovascular risk factors in young population aged 18-29 is essential for the development of screening programs and application of early preventive intervention measures that will reduce cardiovascular diseases in adult age. 


\section{References:}

1. United Nation General Aassembly Resolution A/RES/66/2. New York (2012). Political Declaration of the High-level Meeting of the General Assembly on the Prevention and Control of Non-communicable Diseases. URL: https://www.who.int/nmh/events/un_ncd_summit2011/political_declaration_en.pdf

2. WHO ( 2016). Global Health Estimates. Deaths by cause, age, sex, by country and by region, 2000-2016. URL: https://www.who.int/healthinfo/global_burden_disease/estimates/en/

3. WHO (2018). Noncommunicable diseases country profiles 2018. URL: https://www.who.int/nmh/publications/ ncd-profiles-2018/en/

4. WHO (2018). Global coordination mechanism on the prevention and control of noncommunicable diseases 2016-2017. URL: https://apps.who.int/iris/handle/10665/312273

5. Chiang C.S.J., Singeru T., Yatsuya H., Honjo K., Mita T., Ikerdeu E., Cui R., Li Y., Watson B.M., Ngirmang G. (2015). Profile of Non-communicable Disease Risk Factors Among Young People in Palau. Journal of Epidemiology, 25(5): 392-7.

6. Gupta R.M.A., Vikram N.K., Kondal D., Gupta S.S., Agrawal A., Pandey R. (2009). Younger age of escalation of cardiovascular risk factors in Asian Indian subjects. BMC cardiovascular disorders, 9(1):1.

7. Lau J.S.A.S.H., Irwin C.E., Ozer E.M. (2013). Receipt of preventive health services in young adults. Journal of Adolescent Health, 52(1): 42-49.

8. WHO (2005). The STEPS instrument. In: STEP wise approach to noncommunicable disease risk factor surveillance (STEPS), pp. 311-320. URL: https://www.who.int/ncds/surveillance/steps/riskfactor/en/

9. WHO (2014). Prevalence of Noncommunicable Disease Risck Factors in the Republic of Moldova STEPS 2013. Copenhagen: WHO Regional Office for Europe, pp. 30-219. URL: https://www.who.int/ncds/surveillance/steps/moldova/en/

10. WHO (2017). Belarus STEPS Noncommunicable Disease Risk Factors Survey 2016-2017. Copenhagen: WHO Regional Office for Europe, pp. 45-106. URL: https:/www.who.int/ncds/surveillance/steps/belarus/en/

11. WHO (2018). Non-communicable Diseases Risk-Factors Georgia Survey 2016. Copenhagen: WHO Regional Office for Europe, pp. 8-34. URL: https://www.who.int/ncds/surveillance/steps/georgia/en/

12. WHO (2014). Non-communicable Diseases Risk-Factors Uzbekistan Survey 2014. Copenhagen: WHO Regional Office for Europe. pp.16-48. URL: https://www.who.int/ncds/surveillance/steps/uzbekistan/en/

13. WHO (2016). Non-Communicable Diseases Risk Factors Survey Pakistan. Copenhagen: WHO Regional Ofice for Eastern Mediterranean Region, pp. 14-26. URL: https://www.who.int/ncds/surveillance/steps/pakistan/en/

14. WHO (2016). Kiribati Non-communicable Diseases Risk Factors STEPS Report 2015-2016. Copenhagen: WHO Regional Office for Western Pacific Region, pp. 13-86. URL: https://www.who.int/ncds/surveillance/steps/kiribati/en/

15. WHO (2018). Anguilla Stepwise Survey for Noncommunicable Diseases Risk Factors 2016. Copenhagen: WHO Regional Office for Region of the Americas, pp. 15-41. URL: https://www.who.int/ncds/surveillance/steps/anguilla/en/

16. WHO (2015). Kenya STEPwise Survey for Non-Communicable Diseases Risk Factors 2015 Report. Copenhagen: WHO Regional Office for African Region, pp. 27-97. URL: https://www.who.int/ncds/surveillance/steps/kenya/en/

17. WHO (2015). Survey of Risk Factors for Chronic Non Communicable Diseases State of Kuwait 2015. Regional Ofice for Eastern Mediterranean Region, pp. 65-150. URL: https://www.who.int/ncds/surveillance/steps/kuwait/en/

18. WHO (2017). Noncommunicable Disease Risk Factor Surveillance Data Book for Oman 2017. Regional Ofice for Eastern Mediterranean Region, pp. 8-76. URL: https://www.who.int/ncds/surveillance/steps/oman/en/

19. WHO (2015). National Health \& Nutrition Survey. Non-Communicable Disease Risk Factor Surveillance Report for St. Vincent \& The Grenadines March 2015. Copenhagen: WHO Regional Office for Region of the Americas, pp. 21-53. URL: https://www.who.int/ncds/surveillance/steps/stvincent/en/

20. WHO (2014). Non-Communicable Disease Risk Factor Baseline Survey Uganda Report 2014 Copenhagen: WHO Regional Office for African Region. pp. 40-59. URL: https://www.who.int/ncds/surveillance/steps/uganda/en/

21. WHO (2016). National Survey on the Risk Factors of Non-Communicable Diseases (STEPS) Viet Nam 2015. Copenhagen: WHO Regional Office for Western Pacific Region, pp. 13-86. URL: https://www.who.int/ncds/ surveillance/steps/viet_nam/en/

22. WHO (2017). Zambia STEPS for Non-Communicable Disease Risk Factors for 2017. Copenhagen: WHO Regional Office for African Region, pp. 30-85. URL: https://www.who.int/ncds/surveillance/steps/zambia/en/

23. WHO (2002). The world health report 2002 - Reducing Risks, Promoting Healthy Life. URL: https://www.who.int/ whr/2002/en/

24. WHO (2018). Global Status Report on Alcohol and Health 2018. URL: https://www.who.int/publications/i/ item/9789241565639

25. Todd J.E., Mancino L., B.H. Lin (2010). The impact of food away from home on adult diet quality. USDA-ERS economic research report paper 90.

26. WHO (2014). Global Status Report on Noncommunicable Diseases 2014. URL: https://www.who.int/nmh/ publications/ncd-status-report-2014/en/

27. WHO (2010). Global recommendations on physical activity for health. URL: https://www.who.int/ dietphysicalactivity/global-PA-recs-2010.pdf

28. Zhang Y.X., Wang Z.X., Zhao J.S., Chu Z.H. (2016). Profiles of blood pressure among children and adolescents categorized by BMI and waist circumference. Blood pressure monitoring, no. 21(5), pp. 295-300.

29. Lam, B. C. C., Koh, G. C. H., Chen, C., Wong, M. T. K., \& Fallows, S. J. (2015). Comparison of body mass index (BMI), body adiposity index (BAI), waist circumference (WC), waist-to-hip ratio (WHR) and waist-to-height ratio (WHtR) as predictors of cardiovascular disease risk factors in an adult population in Singapore. PloS one, 10(4), e0122985.

30. Ma, L., Cai, L., Deng, L., Zhu, Y., Ma, J., Jing, J., \& Chen, Y. (2015). Waist circumference is better than other anthropometric indices for predicting cardiovascular disease risk factors in Chinese children-a cross-sectional study in Guangzhou. Journal of atherosclerosis and thrombosis, 31302.

31. Hartz, A. J., Rupley Jr., D. C., Kalkhoff, R. D., \& Rimm, A. A. (1983). Relationship of obesity to diabetes: influence of obesity level and body fat distribution. Preventive medicine, 12(2), 351-357.

32. Graur, L.I., Otilia, N.I.T.A., Popescu, D.S., Mihalache, L., \& Datcu, G. (2011). Corelații între indicii antropometrici şi factorii de risc cardiovascular legați de stilul de viață într-o populație rurală [Correlations between anthropometric parameters and cardio-vascular risk factors related to lifestyle in a rural population]. The Medical-Surgical Journal, 115(3), 705-711.

33. WHO Cardiovascular diseases - Data and statistics. URL: https://www.euro.who.int/en/health-topics/ noncommunicable-diseases/cardiovascular-diseases/data-and-statistics

34. WHO (2011). Global status report on noncommunicable diseases 2010. URL: https://www.who.int/nmh/ publications/ncd_report2010/en/ 